\title{
GEOGRAPHICAL ANALYSIS WITH GIS METHODOLOGY FOR A SUSTAINABLE USE OF LOGGING RESIDUES IN MOUNTAINOUS AREA
}

\author{
Raffaele Cavalli, Stefano Grigolato
}

\section{Introduction}

Productive forest can be highlighted as all land producing forest biomass for industrial and energy use over the forest management planning. Forest biomass for energy purpose includes logging residues, thinned trees and un-merchantable trees [1]. The possibility to use logging residues for supplying heating plants in mountainous area is here evaluated.

In this study, production of forest wood biofuels (wood chips) follows a logical progression from forest biomass to heating or combined heating and power plants (CHP) [2]. In fact forest biomass flow system has to be adapted to the forest resource in one end and to the requirement of mills or heating and CHP plants in the other.

Logging residues are all the amount of tree branches and tops left in terrain or at road side after logging operations (in these case coniferous species). Consequently, in order to use logging residues in area where forestry is one of the most source of income, it is crucial to know the relationship between the annual amount of felled trees and available amount of logging residues.

The feasibility of logging residuals supply chain is complex as it take places in integration with industrial roundwood production. The concept of integration is here understood as a means for most cost effective solutions in harvesting and transport of forest products: roundwood and logging residues chips. Integration of industrial roundwood and wood chips should aim to give cost savings and simplified operations.

It consists on whole tree extraction (WT) by tractor or cable crane and debarking and delimbing operations at roadside by processor.

Paper received 07.12.2006; accepted 15.10.2007

RafFaele CAVAlli, full professor; Stefano Grigolato researcher. Land, Agriculture and Forest Department, Università degli Studi di Padova. Viale dell'Università, 16 I-35020 Legnaro (PD). E-mail: raffaele. cavalli@unipd.it,stefano.grigolato@unipd.it.

Raffaele Cavalli supervised the methodology approach and the editing process. Stefano Grigolato approached the applied methodology, processed the elaborations and edited the text.
Focusing on coniferous trees in mountainous region, Full Trees System (FT) is the most appropriate working system in order to integrate roundwood production and cost-savings availability of logging residues $[3,4]$.

As a result in a specific mountainous area, logging residues availability for energy purpose depends on the FT working system incidence. Investigation on the maximum rate of FT system has to consider working site conditions. Estimating the FT rate for a specific area should be based on the following factors: road network quality and density, terrain characteristics (slope gradient, slope form, topographic complexity and ground roughness) and density and trees size of cut $[5,6,7]$.

For a preliminary evaluation on the potential amount of logging residues availability, the identification of FT system rate results an appropriate approach.

Geographical distributions of logging residues influences the supply chain cost and consequently maximum amount of wood chips that can be economically supplied.

Source site are constrained by prescribed yield (harvested volume) areas that are suitable for FT working system, while sink location depends on heating energy demand (urban area). Therefore Geographic Information System (GIS) become a useful tool to investigate feasibility of logging residues supply chain.

A GIS comprises of a numbers of tools to manage geographical data, produces digital maps and visualises results. It also has a generic set of functions which can be applied to vector and/or raster file in order to model and investigate data and support strategic or tactical planning.

In essence, a GIS can be seen as a decision support system (DSS) which integrates spatially referenced data in a problem solving environment [8].

In order to utilize forest biomass as energy in a forestry region, different GIS methodologies has been applied. In fact, different GIS approaches to quantify forest biomass for energy purpose have been developed in last years $[9,10]$. Also GIS analysis on bio- 
mass transport cost have also been presented [11, 12].

In this study, GIS was used in two different analysis: raster investigation in order to quantify logging residues available for energy use and raster calculation to perform cost-supply analysis for logging residues chips.

Cost-supply analysis was based on cost-weighted distance analysis. It was applied according to terrain, road network characteristic and transporting system.

The innovative aspect of this study consists on defining cost supply curves according to a heating plant demand of wood chips and the geographical distribution of logging residues.

\subsection{Aims}

The objective of this research was to design a GIS methodology that could serve as a decision support system tool for strategic planning on forest biomass for energy use supply chain. A spatial relation between all the data input was used according to a raster-based geographical analysis for the exploration, explanation and determination of logistic costs.

\subsection{Study Area}

In mountainous area, forest work is mainly performed on sloping terrain that affects operational methods, machinery, road network requirement, length of working periods and availability of manpower [13]. Trento Autonomous Province, in the North-eastern part of Italy, evidences a forest area incidence over $50 \%$ and considering altimetrical position, its forest area is completely located in mountainous areas. In this area FT system (applied to coniferous stands) has been increasing in the last decade as often it is considered more efficient than other wood extraction system. For these reasons, logging residues availability and its supply cost investigation was sorted out in Pinè highland located in Trento province.

Pinè highland has a forest coverage of 5400 ha of high forest. Because of its continental climate Norway spruce (Picea excelsa Lamb.) is the predominant tree specie, European Larch (Larix decidua L.), Scotch pine (Pinus sylvestris L.) and Silver fir (Abies alba Mill.) are also commonly spread. Highland growing stock corresponds to 1.16 millions of cubic meter with an annual prescribed cut of $11647 \mathrm{~m}^{3}$ per year.

Pinè highland productive forest ( 3400 ha) has both an even aged and uneven aged structure. Forest management type can be clear strip system (around 5000 $\mathrm{m}^{2}$ ) or patch and group cutting system. Selection cutting is also present but usually is limited to the most irregular stands in higher elevation. Forest is mainly public owned $(80 \%)$.

Pinè highland elevation range from approximately 636 to $2464 \mathrm{~m}$ a.l.s. with a mean and standard deviation of $1342 \mathrm{~m}$. and $365 \mathrm{~m}$ (evaluation by GIS). In the forest, slope gradient range from 0 to $101 \%$ with a mean and a standard deviation of $37.6 \%$ and $19.3 \%$ (evaluation by GIS). Forest road network density inside productive forest area was estimated in $23.1 \mathrm{~m} / \mathrm{ha}$.

\section{Materials and methods}

The logical progression of logging residues from forest to heating or CHP is represented on figure 1.

Different raster analyses were sorted out in order to quantify logging residues availability and to perform cost-supply analysis for logging residues chips.

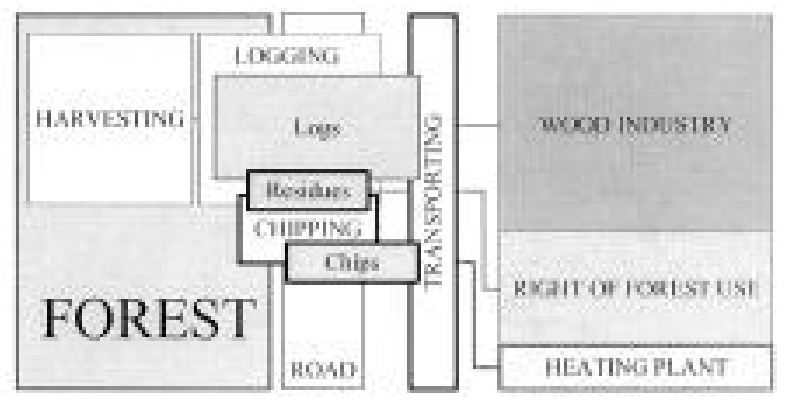

Fig. 1 - Logging residues forest-energy progression.

A generic methods used for modelling distance-induced costs is cost-weighted distance analysis, which, based on modelling resistance across surface cost, returns a least cost travel path and cumulative costs of transport from sources to sinks.

Figure 2 shows analysis framework of the study. This framework shows the flow of data through analysis to produce estimates of biomass stock availability and supply costs for two specifics location.

The GIS models here represented were implemented using ArcGIS 9.1 software [14], including Spatial Analysis for raster analysis.

\subsection{Data acquisition}

One of the most crucial point in developing a GIS model is acquiring and preparing data suitable for the

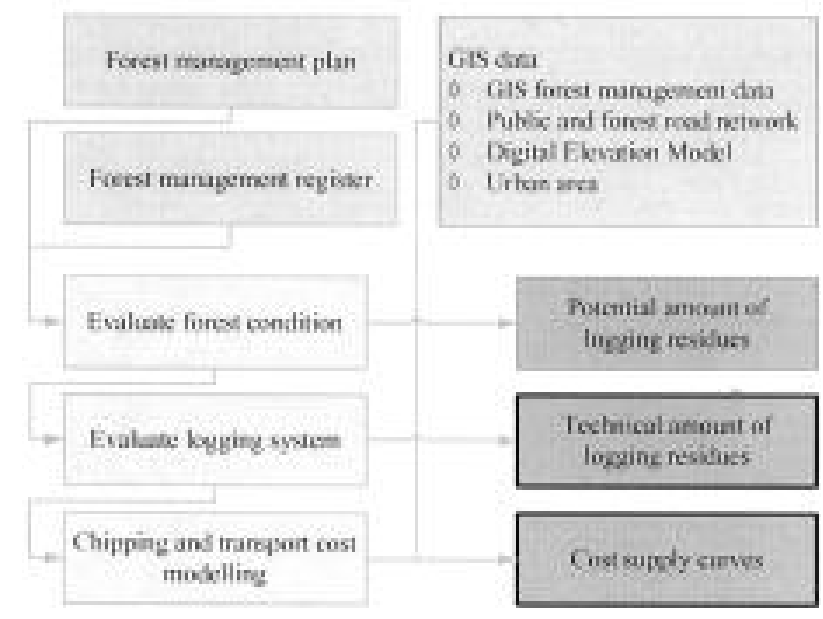

Fig. 2 - Data flow through analysis framework. 
GIS analysis. Here, the data requirements include forest management data, road network characteristics, elevation, chipping and transporting cost, which represent important data sources for all the developed GIS applications of this study.

Forest management registers and yearly cut were collected by the Province forest management Office.

Road network (public and forest) and forest master plans were acquired as vector data. Digital Elevation Model (DEM), used for calculating heights above the sea level and angle of inclination (slope index), consisted in a raster with 20-meter horizontal resolution (cell grid 20mx20m). Chipping and transporting costs were derived by working time study $[15 ; 16]$ for different working sites in mountainous conditions [17].

\subsection{Calculation of annual potential amount}

In short term, the supply of forest logging residues is not constant but fluctuates with the extent of harvesting activities. According to forest management plan, annual prescribed cut corresponds to 11647 $\mathrm{m}^{3} / \mathrm{y}$.

Using GIS methodology for understanding geographic context of wood biomass localisation is the first step in estimating the potential stock available. This methodology is based on integrating forest management geographical data and specific stand volume data (Stand Volume Table, SVT) [19].

Potential quantification is a based on series of calculation that determine the total amount of logging residues. This corresponds to the maximum amount that potentially could be available for local demand. Maximum potential is calculated without the following considerations: logging and extraction system used, spatial relationship between logging residues locations and chips demand site, supply costs. Rights of forest use are considered instead. The result will be identified as Potential Wood Fuel Resource (PWFR). Logging residues are calculated as different percentage on stem content according to SVT (tab. 1).

Calculation of PWFR is based on gaining data from the local forest management plans database and SVT. An algorithmic was applied in GIS elaboration in order to calculate logging residues amount for each stand according to the rate of the four trees species (tab. 1). The GIS algorithmic for PWFR calculation was based on the following formula:

$$
P W F R=\left[\sum_{i=i}^{N}\left(S S V_{r}-S V_{r}\right) \times\left(\beta_{s p}-S t_{s p p}+B T_{s p p}\right)\right] \times c v
$$

[PWFR: total amount of logging residues chips ( $\mathrm{m}^{3}$ loose); sp: tree species; $S V$ c: stem volume - prescribed cut $\left(m^{3}\right)$; $S V r$ : stem volume - right of forest use $\left(\mathrm{m}^{3}\right) ; B$ : bark (\%); SL: sawing loss (\%); BT: branches and tops (\%); cv: conversion coefficient, $\left(\mathrm{m}^{3}\right.$ loose $\left.\left.\mathrm{m}^{-3}\right)\right]$

Results can be explained in loose cubic meter $\left(\mathrm{m}_{\text {loose }}^{3}\right)$ or in tons as commonly used for measuring wood chips. Chips volumetric coefficient $(c f)$ range from 2.5 to 3.0. Conversion factors from solid cubic

\begin{tabular}{|l|c|c|c|c|}
\hline & Spruce & Fir & Larix & Pine $s v$ \\
\cline { 2 - 5 } & {$[\%]$} & {$[\%]$} & {$[\%]$} & {$[\%]$} \\
\hline Bark (B) & 10 & 10 & 20 & 15 \\
\hline Sawing loss (SL) & 5 & 5 & 5 & 5 \\
\hline Branches $(<7 \mathrm{~cm})$ and tops (BT) & 14 & 14 & 14 & 14 \\
\hline TOTAL & 29 & 29 & 39 & 34 \\
\hline
\end{tabular}

TABLE $\quad 1$ - Percentage of logging residues [19].

meter to loose cubic meter depends on chips size and therefore chipping process and machine. The size of chips is related to wood density, growth-ring orientation, moisture content and chipper cutting system (drum or disk cutting system).

In this context a conversion factor $(c f)$ of 2.7 was applied. According to field analysis on logging residues chips production in mountainous forest area, moisture contents of logging residues range from $50 \%$ to $55 \%$ (wet basis). These value has to be referred for chips of green logging residues. For dry wood and wood with moisture contents of $50 \%$ (wet basis), Low Heating Value (LHV) and volumetric density are reported on table 2 .

\begin{tabular}{|l|l|c|c|c|c|}
\hline & & Spruce & Fir & Larix & Pine $s v$ \\
\hline $\mathrm{LHV}_{0}$ & $\mathrm{MJ} \mathrm{kg}^{-1}$ & 19.32 & 19.19 & 19.04 & 19.47 \\
$\rho_{0}$ & $\mathrm{~kg} \mathrm{~m}^{-3}$ & 410 & 410 & 590 & 480 \\
\hline $\mathrm{LHV}_{50}$ & $\mathrm{MJ} \mathrm{kg}^{-1}$ & 8.44 & 8.38 & 8.30 & 8.45 \\
$\rho_{50}$ & $\mathrm{~kg} \mathrm{~m}^{-3}$ & 720 & 730 & 1045 & 840 \\
\hline
\end{tabular}

TABLE 2 - Low heating value and volumetric density [19; 20].

These values can be used to calculate the weight in tons of one cubic loose meter as follows:

$$
P W F R_{w}=\left[\sum_{i=1}^{N}\left(P W F R_{s p} \times \rho_{s p}\right)\right] \times 1000
$$

$\left[P W F R_{w}\right.$ : total amount of logging residues chips $(t) ; \rho$ : wood density $\left.\left(\mathrm{kg} \mathrm{m}^{-3}\right)\right]$

In the end, results are integrated into Geographic Informatics System to evidence the distribution of the potential amount of logging residues for each different productive stands in the highland.

\subsection{Calculation of annual technical amount}

Technical logging residues amount suitable for energy use is here evaluated according to extraction systems. Where technically trees could be extracted by tractors and winch, the work methods supposes to top and delimb trees at stump (Tree Length System, system A) and consequently to extract them by ground skidding; as an alternative, where whole trees could be extracted through a cable crane, the work method considers topping and delimbing of tree at roadside by means of a processor (Full Tree System, system B). 
Only system B lets to heap logging residues at roadside. As consequence, system B was considered a cost-saving working system for supplying logging residues for energy availability. In fact, logging residues are available at roadside without any costs as all logging and extraction costs are supported by commercial assortments. In this study tree are supposed to be partially delimbed at stump. For system B, the logging amount of residues left at stump is supposed to be $15 \%$ of the total logging residues.

GIS investigation was applied in order to define area suitable for system A and system B. Considering that steepness and road network density of productive forest influence logging methods, a GIS based investigation results a suitable tool for mapping forest area according to one system rather than another one.

Working system allocation is here evaluated on: terrain steepness (slope gradient) and hauling distance. Table 3 illustrates the two input factors and their limit value.

According to precedent investigations [7;21], for system $\mathrm{A}$ the maximum extraction distance is fixed in $100 \mathrm{~m}$ (both uphill and downhill). As steepness has more influence on downhill than on uphill ground extraction, a maximum slope of $35 \%$ is considered for downhill ground extraction.

Identification of System B suppose to use a all-terrain cable crane. This cable crane lets to extract trees both downhill and uphill. Maximum hauling distance is here fixed in $800 \mathrm{~m}$.

\begin{tabular}{|c|c|c|c|c|}
\hline System & Distance & Distance & Slope & Slope \\
\hline & Uphill & Downhill & Uphill & Downhill \\
\cline { 2 - 5 } & $\mathrm{m}$ & $\mathrm{m}$ & $\%$ & $\%$ \\
$\mathrm{~A}$ & 100 & 100 & 35 & 25 \\
$\mathrm{~B}$ & $0-800$ & $0-800$ & 100 & 100 \\
\hline
\end{tabular}

TABLE 3 - Working system limits for GIS matrix.

The GIS matrix developed does not consider stand density and harvesting intensity. A GIS approach for a large scale application can not evidence these parameters without precise field surveys by GPS tools.

As the application here presented is suitable for a strategic evaluation on the feasibility to supply a heating plant by local logging residues, field surveys on density and harvesting density are not considered. Once forest area is characterised according to the most suitable working system, technical logging residues availability can be estimated. Raster layer that represents potential logging residues allocated over the forest productive area is overlaid to the working system allocation raster. The technical amount of logging residues that can be heaped at road side is following highlighted.

\subsection{Supply costs}

The assessment of logging residues chips is based on the amount highlighted from technical logging residues availability result. This section deals with the supply costs of logging residues chips production. Supply costs supposes: chipping and transporting costs.

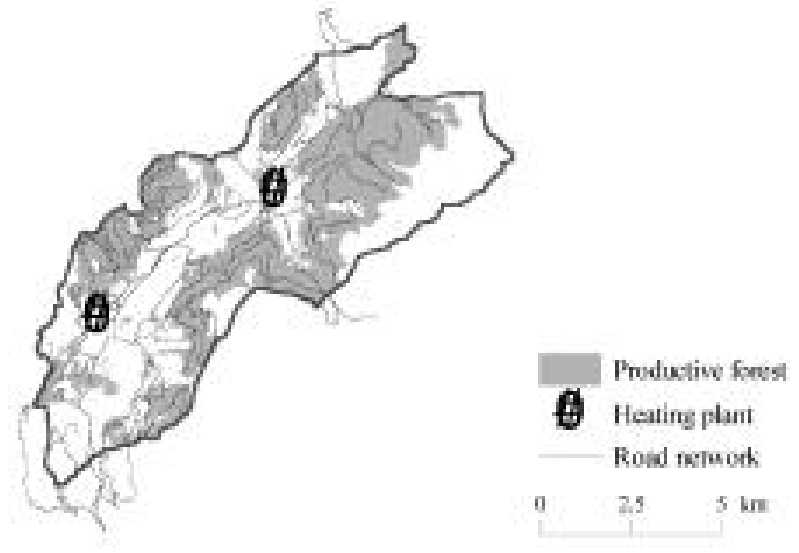

Fig. 3 - Pinè highland and heating plant scenario.

Two scenarios were investigated. Scenario A supposes that heating plant is located in a marginal area in the southern part of the highland. Scenario B supposes heating plant in the centre of the investigated area (fig. 3), thus closer to productive forest area.

Chipping cost is defined for a specific high productivity chipper (tab. 4). According to the material typology and working site condition (landings at road site), chipping cost is evaluated in $19.6 € / \mathrm{t}$ with a $50 \%$ of moisture content (on wet basis).

\begin{tabular}{|l|l|c|}
\hline Chipper Characteristics & Unit & Value \\
\hline Engine Power & $\mathrm{kW}$ & 335 \\
Maximum piece size $(\varnothing)$ (hard - soft wood) & $\mathrm{cm}$ & $42-56$ \\
Drum $(\varnothing)$ & $\mathrm{cm}$ & 82 \\
Knife & $\mathrm{n}^{\circ}$ & 10 \\
Productivity & $\mathrm{t} \mathrm{h}^{-1}$ & $7.5-10$ \\
Chipping cost & $€ \mathrm{~h}^{-1}$ & 150 \\
\hline
\end{tabular}

TABLE 4 - Drum chipper characteristics.

As in many other supply chain, also in logging residues supply chain transporting costs are affected by transporting time. Detailed analysis of transport costs can result complicated. In this study, assumptions have been made to derive a simple cost formula as:

$$
Y=A+B x
$$

[Y: total transport cost - back hauling included $\left(€ t^{-1}\right) ; X$ : one-way haul $(\mathrm{km})$ ]

Transporting is here supposed to be performed by a truck with a $36 \mathrm{~m}^{3}$ volumetric capacity. The average speed in forest road network was estimated in 15.1 $\mathrm{km} / \mathrm{h}$, while an average speed of $46.1 \mathrm{~km} / \mathrm{h}$ was estimated for public road network. A and B in (3) can depend on a multitude of factors like travel speed, truck 
type, residues characteristics and road conditions. In this study, chipping and transporting cost formula corresponds to:

$$
Y=2.79+1.52 X
$$

[Y: total transport cost - back hauling included (€ $\left.t^{-1}\right) ; X$ : one-way haul (km); moisture content: 50\%; $c f: 2.7\left(\mathrm{~m}^{3}{ }_{\text {loose }}\right.$ $\left.\left.m^{-3}\right)\right]$

Formula 4 is derived by considering that trucks run $5 \mathrm{~km}$ along forest road network and remaining along public road network.

\subsection{Supply cost modelling}

Economic reasons limits maximum transport distance and thus the economic supply area. Here the supply cost modelling considers supply cost on: road infrastructure and its efficiency, stand locations and chipping working site. Supply cost for each tons of chips (50\% moisture contents and cf 2.7) at heating plant is defined as:

$$
C=V c+F c
$$

$\left[C:\right.$ total cost - transporting and chipping cost $\left(€ t^{-1}\right) ; V c$ : variable cost - transporting ( $\left.€ \mathrm{t}^{-1} \mathrm{~km}\right) ; \mathrm{Fc}$ : fix cost- chipping $\left.\operatorname{cost}\left(€ t^{-1}\right)\right]$

Here, in order to get sufficient spatial resolution in determining marginal delivery costs, each grid cells (grid resolution $20 \mathrm{~m} \times 20 \mathrm{~m}$ ) are treated as individual supply sources. Fixed cost represents the cost for chipping logging residues, including loading and unloading costs (working site cost). A raster layer is elaborated in order to spatially represent fix cost for each grid cell according to logging residues amount. Fix cost $(F c)$ corresponds to $19.8 € / \mathrm{t}$ (chipper productivity is estimated for this monotonous area in $7.6 \mathrm{t} / \mathrm{h}$ ).

Variable cost represents transport cost of one ton over one kilometre: a specific approach is used to get spatial value to this cost. In fact, in this study forest and public road networks (commonly represented by vector data) are not considered. Transporting cost is based on a "weighted distance" raster. On first, through raster calculation, a winding coefficient $(W I N c)$ is calculated to find out the weighted distance inside each pixel. For each raster cell, weighed distance or winding coefficient calculation is based on slope gradient. WINc is commonly used to measure the distance of a real transport route from one source point to a user location $[6 ; 10 ; 11]$. Here, $W I N c_{i}$ is calculated in order to estimate transporting distance inside each raster cell.

$$
W / \mathrm{NC}_{j}=\frac{\mathrm{Si}_{j}}{\mathrm{Sr}}
$$

[WINc $c_{i}$ : winding coefficient; $\mathrm{Sl}_{i}$ : slope gradient (\%); Sr: standard road slope gradient (\%)]

$\mathrm{Sr}$ value represents standard road slope gradient. For this area $8 \%$ value was considered. Maximum value of winding coefficient is evaluated in 2.25 . It corresponds to the ratio between maximum road slope gradient (18\%) and road standard slope gradient (8\%). For slope gradient over $18 \%$, the WINc is fixed to 2.25 , while for slope gradient lower than $8 \%$ is fixed in (1). It means that for crossing a cell, the distance can range from 20 to $45 \mathrm{~m}(20 \mathrm{~m} \times 1$ or $20 \mathrm{~m} \times 2.25)$. Slope gradient is calculated as percentage by calculation based on DEM raster [14].

Distance from each raster cell to heating plant is consequently determined by Cost Weighted Distance allocation [14]. The Cost Weighted Distance function modifies the straight line distance by some other factor which is a kind of "friction" to travel through any given cell. In fact, distances between heating plant and each raster cell are calculated as minimum weighted distance between two point (cell- $i$ and heating plant).

In this way, cost weighted distance allocation lets to find the least accumulative distance from each cell to the heating plant. Travel cost is here evaluated for the GIS calculation in $0.22 € / \mathrm{t}$ per $\mathrm{km}$. In this study. the travel cost (friction) for each cell is $V c_{i}$.

$$
v_{c_{j}}=\frac{\left(\frac{s_{i}}{s_{r}}\right)}{V_{0,0}}+x_{i}
$$

[Vc $c_{i}:$ supply cost for one ton to cross raster cell-i $\left(€ t^{-1}\right)$; $V c$ : variable cost - (€ $\left.\mathrm{t}^{-1} \mathrm{~km}\right)$; $\mathrm{Sl}_{i}$ : slope gradient (\%); $\mathrm{Sr}$ : standard road slope gradient (\%); Tc: travel cost (€/t km)]

The weighted distance is thus calculated for each raster cell by computing the accumulative friction $\left(V c_{i}\right)$ from the same raster cell to the heating plan.

As the GIS function cumulates the inverse weighted distance, resulting distance value $(V c)$ will be assigned to the same raster cell. $V c$ will be the transport cost for supplying one ton of chips (transporting), inside a $i$-pixel spatially defined, to the heating plant. Consequently for each ton of chips, $\mathrm{C}$ results by summing $V c$ raster cost to $F c$ raster cost.

\subsection{Supply cost curves}

The transport cost calculation is site specific. Thus it has to be repeated for both the heating plant sites (scenario A and scenario B).

The result of a specific transport cost calculation is a continuous grid, which holds value for transporting costs per ton. Cost supplies curves are consequently derived through zonal statistics. The continuous grid of transporting costs is subdivided into cost classes (from $8 € / \mathrm{t}$ to $40 € / \mathrm{t}$ ): each cost class is spatially distributed on the study area. Transporting costs can be supposed as the zone theme, while the technical amount of logging residues become the theme to be summarised. As consequents the available amount of logging residues can be classified according its supply cost.

With the zonal statistics function in ArcGIS Spatial Analyst [14], summarising the amounts for each instance of transportation costs returns a site-specific 
frequency distribution of costs and amounts. In this way it is possible to calculate the average costs for accumulated amounts of logging residues chips. The result can be represented as a cost-supply curves. Cost supply curves can be statistically described by regression analysis. As consequence the resulting regression functions can be used to calculate site specific chips costs depending on local demand.

\section{Results}

\subsection{Annual potential amount}

According to forest management plans, the annual prescribed cut is equal to $6753 \mathrm{~m}^{3}$ (tab. 5). Spruce is the most cut tree specie. It corresponds to $2 / 3$ of total prescribed cut. Annual potential amount calculation is based on annual prescribed cut screened from population right for forest use.

\begin{tabular}{|c|c|c|c|c|c|}
\hline & Spruce & Fir & Larix & Pine sv & TOTAL \\
\hline $\mathrm{m}^{3}$ & 5023 & 353 & 597 & 780 & 6753 \\
$\%$ & 66 & 4 & 10 & 20 & 100 \\
\hline
\end{tabular}

TABLE 5 - Annual prescribed cut according to population right for forest use.

On the basis of values reported in table 1 and table 2 , the potential amount of logging residues chips (moisture content 50\% - wet basis and $c f: 2,7 \mathrm{~m}^{3}$ loose) was calculated according the method described in paragraph 3.2. The potential amount is reported both in cubic loose meter and in ton (fig. 4) (tab. 6). Potential energy content in $\mathrm{MJ}$ is also reported. Potential amount can contain at least 13904 GJ, according to logging residues moisture contents.

\subsection{Technical amount}

According to GIS calculation, system B could be applied over $65 \%$ (2200 ha) of the productive forest area. As technical quantification assumes that $15 \%$ of
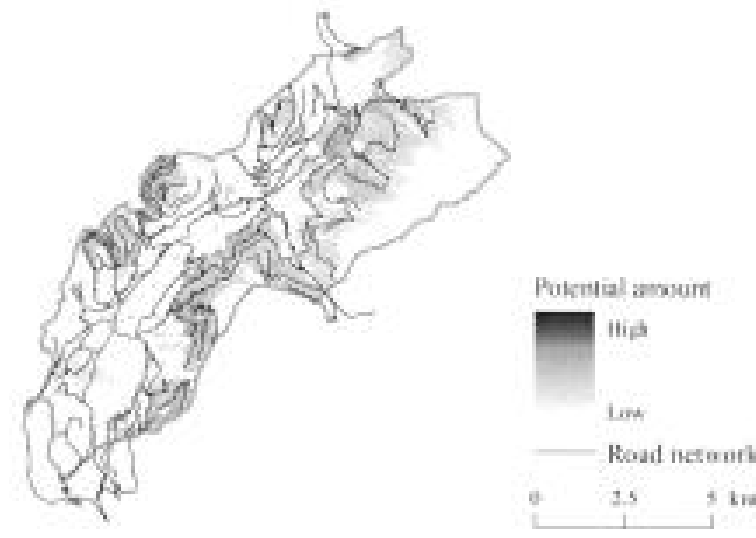

Fig. 4 - Logging residues potential amount.

\begin{tabular}{|c|c|c|c|c|c|}
\hline & Spruce & Fir & Larix & Pine sv & TOTAL \\
\hline $\mathrm{m}_{\text {loose }}^{3}$ & 3742 & 260 & 590 & 754 & 5346 \\
$\mathrm{t}$ & 1403 & 96 & 152 & 242 & 1528 \\
$\mathrm{GJ}$ & 11840 & 803 & 1261 & 2045 & 13904 \\
\hline
\end{tabular}

TABLE 6 - Potential amount of logging residues PWFR.

logging residues remains at stump, the resulting amount corresponds to 869 tons per year. Technical quantification estimates an amount of logging residues and an available energy about $43 \%$ less then the value evidenced as potential amount.

That depends on the possibility to extract whole trees from stands to roadside or landing. In this study, the possibility to extract whole tree is referred to cable extraction. If the clear cut is contiguous to roadside, the extraction of whole tree can be supported by tractor and winch system (maximum diameter of 35 $\mathrm{cm}$ ). That increases the possibility to heap logging residues at roadside. In fact a processor mounted on a tractor can easily work at roadside.

\begin{tabular}{|c|c|c|c|}
\hline & PWFR & Technical amount & $\Delta$ \\
\hline $\mathrm{m}_{\text {loose }}^{3}$ & 5346 & 3040 & -2306 \\
$\mathrm{t}$ & 1893 & 869 & -659 \\
$\mathrm{GJ}$ & 13904 & 7925 & -5979 \\
\hline
\end{tabular}

TABLE 6 - Technical amount of logging residues.

\subsection{Modelling}

Geographical analysis on logging residues chips supply cost presents two scenarios. For each of these two scenarios the least supply cost surface is calculated according to methods reported in 3.5 (fig. 5 and fig. 6). The least supply cost layer derived by GIS operation that sum chipping cost to transporting costs. In this way, supply costs are spatial-referenced.

Transporting costs surface are based on a Cost Weighted Distance allocation. The travel cost depend on the spatial variability of the winding coefficient

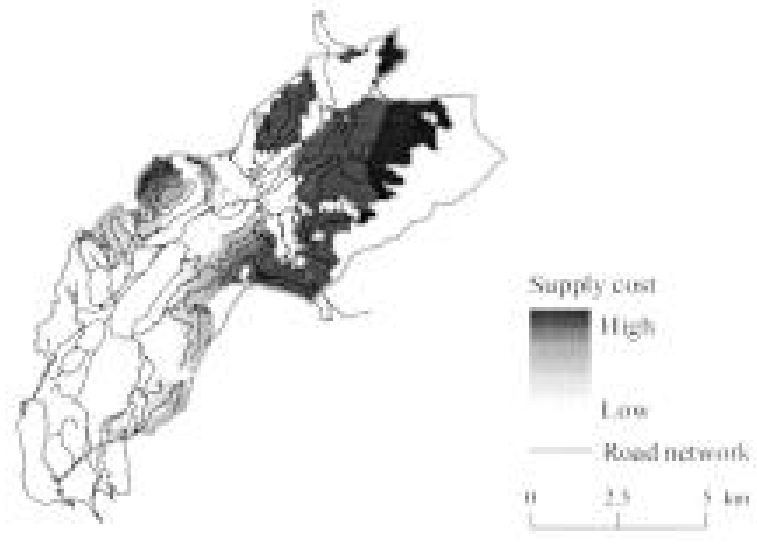

Fig. 5 - Least supply cost surface for scenario A. 


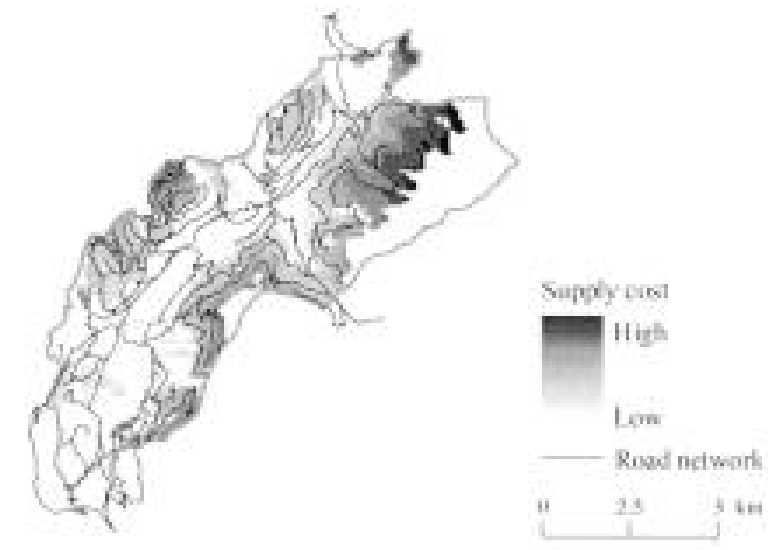

Fig. 6 - Least supply cost surface for scenario B.

$(W I N c)$. Figure 5 evidence the spatial variability of $W I N c$ calculated according the methods presented in 3.5. Winding coefficient presents higher average value in forest area. That confirms the high cost on supplying chips from forest in mountainous conditions.

\subsection{Supply cost curves}

With the methodology presented in 3.6, cost supplies curves have been defined for each of the supposed scenarios (fig. 8). These supply cost curves are specific for the scenarios investigated. They depend on productive forest distribution, chipping cost and transporting cost, as they are specified above.

According to the results on technical quantification, the annual demand could range from 0 to 869 tons per year. Here, the regression of the supply cost curves arrives up to 1000 tons. The most feasible annual demands can range from 200 to 600 tons per year. For each of the presented scenarios, the average cost per delivered ton is reported. $\Delta \mathrm{T}$ represents the difference between the annual delivering cost of scenario B and scenario A. The supply curves evidence average costs of biomass over accumulated amounts. By comparing the two curves (scenario A and scenario $\mathrm{B}$ ), the effects of local productive forest distribution become quite clear.

Scenario B represents a cost supply curves of a heating plant located in good position as regards the

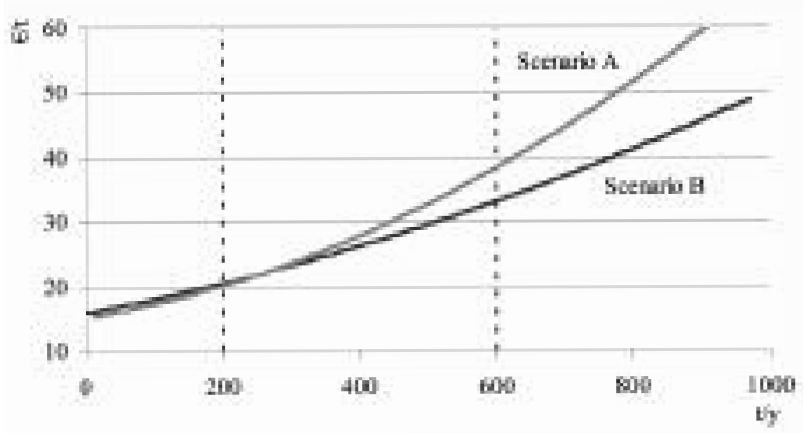

Fig. 8 - Cost supply curves.

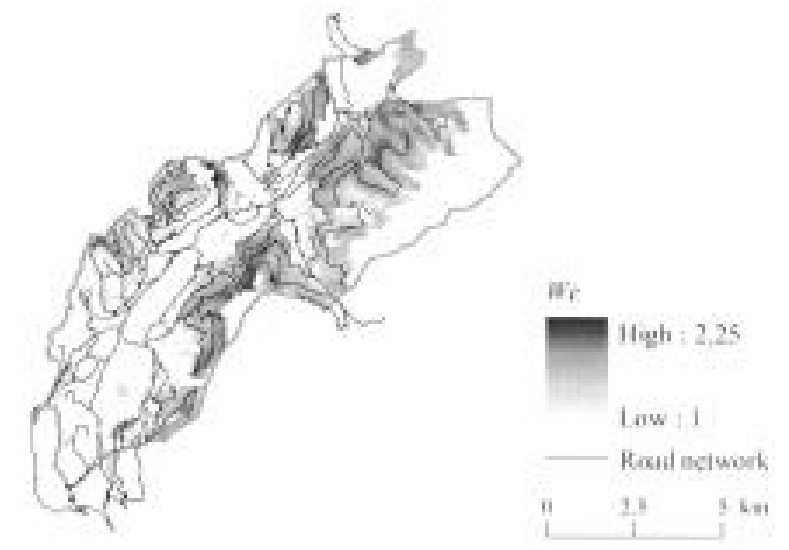

Fig. 7 - Model-designed winding coefficient (WINc).

\begin{tabular}{|c|c|c|c|c|}
\hline Amount & Scenario A & Scenario B & $\Delta i$ & $\Delta \mathrm{T}$ \\
\hline$[\mathrm{t} / \mathrm{y}]$ & {$[€ / \mathrm{t}]$} & {$[€ / \mathrm{t}]$} & {$[€ / \mathrm{t}]$} & {$[€ / \mathrm{y}]$} \\
\hline 100 & 17 & 18 & -1 & -54 \\
200 & 20 & 20 & 0 & 39 \\
300 & 24 & 23 & 1 & 346 \\
400 & 28 & 26 & 2 & 961 \\
500 & 33 & 29 & 4 & 1999 \\
600 & 39 & 33 & 6 & 3614 \\
700 & 45 & 37 & 9 & 5998 \\
800 & 53 & 41 & 12 & 9397 \\
900 & 62 & 47 & 16 & 14123 \\
1000 & 73 & 53 & 21 & 20565 \\
\hline
\end{tabular}

TABLE $\quad 7$ - Potential amount of logging residues PWFR.

productive forest area. In fact, in this part of the highland a heating plant can be easier supplied than a heating plant located in the southern part. If the annual demand is over 300 tons (moisture content $50 \%$ wet basis), the location will play a strategic role for the supply cost. As reported on table 6, the different effects of location on the potential annual demand on chips are evidenced.

Scenario A is more sensitive in supply cost than scenario B. In fact, for an high chips demand scenario B present a supply curve less inclined than for scenario A. When chips demand is less than 300 tons, the location of the heating has not so influence on the final supply cost.

\section{Conclusions}

The rising interest on verifying the possibility of use forest biomass for energetic use has determined the development of different assessment approaches.

A specific assessment methodology has been developed for evaluating the feasibility of use logging residues for supplying a potential district heating system located in a mountainous district. In this study, the chipping and transporting costs for forest wood 
chips are analysed for two supposed localisation for a heating plant placed on a mountainous area.

Mountainous terrain characteristics (mainly slope grade and roughness) influence logging systems applications. Full Tree logging system is considered one of the most cost effective solution in alpine condition. This logging system can be integrated also with forest-wood-energy chain. Where Full Tree system could be adopted, logging residues are heaped close to the landing site. Consequently, these logging residues could be easy chipped for energetic utilization. In fact, integrating logging system by chipping operation could be considered a cost effective solution to supply chips from forest to a heating plant.

Logging residues availability is not enough for determining the economic feasibility of a heating plant. The localisation of the district heating or heating plant plays a strategic role, especially in mountainous condition. A well localized heating plant (in relation of productive forest area and in relation to heating demand) could have an advantage in terms of supply cost.

It is important to highlight also the quality level of this delivered forest chips. Logging residues chips present low quality because of high moisture content, high ash contents and irregular dimensional size. These factors limits the use of logging residues chips in small heating boilers. For these reason the feasibility of a forest-wood-energy chain depends on boiler technology too. The most appropriate technology is the direct combustion in fixed-bed combustion system (grate furnace system). Here, primary air passes through a fixed bed in which drying, gasification and charcoal combustion takes place. Grate furnaces are appropriate for wood biomass fuels with high moisture contents and high ash contents [22]. The most appropriate grate furnaces for this solid biofuel present, usually, inclined and moving grate. This combustion system presents high power size, usually over $300 \mathrm{~kW}$ [23]. Hence, an accurate and precise quantification of logging residues availability and its supply cost becomes, indispensably.

\section{References}

[1] UNI CEN/TS 14588, Solid biofuels. Terminology, definitions and descriptions, (2004).

[2] AsiKaINEN A., Integration of work tasks and supply chains in wood harvesting. Cost savings or complex solutions? International Journal of Forest Engineering, (2004), 2, 11-17.

[3] Spinelli R., Nati C., Fabbri P., Production of fuel chips from logging residues at cable landing, on proceeding of New trend in wood harvesting with cable system for sustainable forest management in the mountain, FAO/ECE/ILO/IUFRO (2003), Ossiach, 18-24 June.

[4] Cavalli R., Confalonieri M., Zamboni R., Approvvigionamento di dendromassa per usi energetici, Sherwood, Foreste ed Alberi Oggi, (2003), 9, 3, 11-16.

[5] Cavalli R., De Benedet B., Menegus G., Cable crane utilisation in the close-to-nature silviculture in the Upper Piave River Valley, on proceedings of New trend in wood harvesting with cable system for sustainable forest management in the mountains, FAO/ECE/ILO/IUFRO (2003), Ossiach, 18-24 June.

[6] SundBerg U., Silversides C.R., Operational Efficiency in Forestry, Vol. 1, Analysis Forestry Sciences, Kluwer Academic Publishers (1988), Dordrecht, 219 pp.

[7] Fabiano F., Marchi E., Gru a cavo forestali: diffusione attuale e possibilità d'impiego, Sherwood, Foreste ed Alberi Oggi, (2001), 7, 5, 43-47.

[8] Burrough P.A., Mcdonnell R.A., Principles of Geographical Information Systems, Oxford University Press Inc. (1998), Oxford, 332 pp.

[9] Voivontas D., Assimacopoulos D., Koukios E.G., Assessment of biomass potential for power production: a GIS based method, Biomass and Bioenergy, (2001), 20, 101-112.

[10] RANTA T., Logging residues from regeneration fellings for biofuel production. A GIS-based availability and supply cost analysis, Lappeenrannan teknillinen korkeakoulu, Acta Universitatis Lappeenrataensis (2002), 128, Lapperanta, $182 \mathrm{pp}$.

[11] Bernetti I., FAgARAZZI C. Biosit: una metodologia GIS per lo sfruttamento efficiente e sostenibile della "risorsa biomassa" a fini energetici, D.E.A.R.T, Dipartimento di Economia Agraria e delle Risorse Territoriali (2003), Firenze, 189 pp.

[12] Van Belle J.F., Temmerman M., Schenkel Y. Three level procurement of forest residues for power plant, Biomass and Bioenergy, (2003), 24, 401-409.

[13] Cavalli R., Le utilizzazioni forestali nell'Italia Nordorientale, L'Italia Forestale e Montana, (2004), 6, 453-465.

[14] Mitchell A., Geographic Patterns and Relantionships, The ESRI Guite to GIS Analysis, Enviromental System Research Center, (2003), Redlands, CA, 186 pp.

[15] Berti S., Piegai S., Verani S. Manuale di istruzione per il rilievo dei tempi di lavoro e delle produttività nei lavori forestali, Quaderni d'Istituto di Assestamento e Tecnologia Forestale, Fascicolo IV, Istituto di Assestamento Forestale, Faculty of Agricolture, Università degli Studi di Firenze, (1989), Firenze, 63 pp.

[16] MiYata E.S., Determining fixed and operating costs of logging equipment, North Central Forest Experiment Station, Forest Service, USDA, (1980), St.Paul, $\mathrm{MN}, 16 \mathrm{pp}$.

[17] Grigolato S., RAise A., 2005. Produzione di cippato in ambiente alpino, Supplement at L'Informatore Agrario, (2005), 35, 19-22.

[18] Provincia Autonoma Di Trento, Abete bianco, abete rosso, larice e pino silvestre della Regione Trentino - Alto Adige. Tavole alsometriche, Assessorato dell'Agricoltura e Foreste della Regione Trentino - Alto Adige. (1956), Trento.

[19] Kollmann F.F.P., Technologie des Holzes und der Holzwerkstoffe, Springer (1951), München.

[20] Tsoumis G., Science and technology of wood: Structure, properties, utilization, Van Nostrand Reinhold, (1991), New York, 494 pp.

[21] Piegai F., Produttività dell'esbosco con gru a cavo in confronto all'esbosco per avvallamento ed all'esbosco a strascico con trattor, L'Italia Forestale e Montana, (1990), 6, 419-439.

[22] Van Loo S., Koppejan J., Handbook of biomass. Combustion and co-firing, Twente University Press (2003), Enshede, 348 pp. 
[23] Pellerano A., Pantaleo A., Biomass energy surveying and techno-economical assessment of CHP: an application to Basilicata Region, Rivista di Ingegneria Agraria (2005), 2, 25-34.

\section{SUMMARY}

A GIS-based approach is presented in order to define a decision support system tool for strategic planning of forest biomass supply chain for a heating/energy use. The presented GIS-based approach focus its analysis on forest management data, road network characteristics, terrain features and chipping and transporting cost. According to two different heating plants location, results on the availability of logging residues for energy use are presented in form of cost supply curves. For the investigated case study, supply curves evidence that, also at local level, different locations of heating plants can affect the cost-efficient use of logging residues in form of wood chips.

Key words: Forest Operations, GIS, Logging residues, Wood Energy. 


\section{2nd ICID European Regional Conference on Water Resources Management and Irrigation and Drainage Systems Development in the European Environment}

Water resources management should preserve or enhance the environment's buffering capacity to withstand unexpected stress or negative long term trends. As the environment's carrying capacity is put under increasing pressure, due to the growing needs of the population and improper use of natural resources, environmental vulnerability increases too. In this context ,mismanagement of water resources, paying only lip service to the environment , has led to water scarcity and water pollution which threaten food security and the quality of human life.

All these factors compel scientists, technicians and decision-makers to review the strengths and weaknesses of current trends in water resources management and irrigation and drainage development and rethink technology, research thrust and institutional and financial patterns, so that service levels and system efficiency can be improved and sustainable use of water resources pursued.

On these themes the $22^{\text {nd }}$ European Regional Conference of ICID took place in Pavia, Italy, on 2-6 September 2006. The Event was organized by the Italian national committee of ICID (ITAL-ICID) with the co-sponsorship and scientific support of different national and international Institutions, among which is worth mentioning the Italian Districts of Lombardia and Lazio, CIGR, EurAgEng, IPTRID and WWC.

The Conference was attended by over 150 delegates from 19 countries. It provided an opportunity to review not only the present European practices in integrated water resources management and irrigation and drainage systems development ,but looked beyond and explored what Europe could contribute to the rest of the world as leading regional player who had been well known for its "outward facing".

The importance of the Conference was underlined by the presence of several ICID Office Bearers, including President Peter Lee, President Hon. Bart Schultz, Vice Presidents Lübbe and Guluyk, Vice Presidents Hon. Segura Graino , Alain Vidal and Ligetvàri, Secretary General Gopalakrishnan and Secretary Sharma, besides the members of the host Italian national committee, including ITAL-ICID President Lucio Ubertini, General Secretary Maria Elisa Scarascia and the Conference Co-chairman Daniele De Wrachien, EurAgEng Past President.

The four Conference Sessions: "Impacts of Extreme Hydrological Events on Irrigation and Drainage Systems", "Energy Saving Technology in Advanced Irrigation Systems", "Conjunctive Use of Surface and Groundwater" and "Participatory Management and Economic Policies for Irrigation and Drainage Development", attracted submissions of almost 80 papers from several countries.

Two Workshops on "History of Irrigation, Drainage and Flood Control" and on "European Framework Directive in the Field of Water" were also successfully organized during the Conference. The aim of the first Workshop was to analyse the history in such a way that lessons can be learned for present day approaches and practices in the fields of land reclamation, flood control, irrigation and drainage in Europe. The second one focused its attention on measures suitable to prevent water deterioration, protect and restore all bodies of groundwater and ensure a lasting balance between withdrawal and recharge of subsurface water resources. It was decided to bring out a "Pavia Initiative" as the outcome of the Conference. The International Event concluded with two field trips to the irrigation and drainage systems, land reclamation works and flood protection projects in the provinces of Novara and Mantua.

Prof. Peter Lee

ICID President

Prof. Daniele De Wrachien

EurAgEng Past President 